\title{
Morphological analysis of gutta-percha points subjected to different treatments and the influence on obturation sealing
}

Análise morfológica de cones de guta-percha submetidos a diferentes tratamentos e sua influência no selamento da obturação
Patrícia Campos Ferreira da ROSA

DDS, MsC - Department of Restorative Dentistry - School of Dentistry of São José dos Campos - UNESP - Univ Estadual Paulista São José dos Campos - SP - Brazil

Simone Helena Gonçalves de OLIVEIRA DDS, MsC, PhD - Departament of Bioscience and Oral Diagnosis School of Dentistry of São José dos Campos - UNESP - Univ Estadual Paulista - São José dos Campos - SP - Brazil

Rafaela Andrade de VASCONCELOS DDS, MsC - Department of Restorative Dentistry - School of Dentistry of São José dos Campos - UNESP - Univ Estadual Paulista São José dos Campos - SP - Brazil

\begin{abstract}
Objective: This study evaluated the morphological alterations, through scanning electronic microscopy (SEM), which occur in the gutta-percha points exposed to periods longer than those recommended. Material and method: $2 \%$ chlorhexidine (CLX), 2.5\% sodium hypochlorite (NaOCL), $2 \%$ peracetic acid (PA) and $0.25 \%$ peracetic acid solution (PAS) were the solutions used for the following periods: $1 \mathrm{~min}, 30 \mathrm{~min}, 6 \mathrm{~h}$ and $12 \mathrm{~h}$. The groups were divided according to the solution and disinfection period $(\mathrm{n}=12)$. Results: The results indicated that there was statistically significant differences among the solutions and period tested. At $1 \mathrm{~min}$, all solutions did not differ from the control group. After $30 \mathrm{~min}$, PAS significantly altered the morphology of the points. The energy dispersive spectrometry (EDS) test indicated that all substances and periods altered the chemical composition of the gutta-percha points. At $12 \mathrm{~h}$, the effect of disinfection on the obturation leakage was also evaluated Accordingly, PAS showed statistically significant differences in relation to control group, because $100 \%$ of the roots exhibited leakage. The other groups (CLX, NaOCL and PA), although without statistical differences, showed 9,8 and 8 out of 12 roots with leakage, respectively. Conclusion: It can be concluded that the disinfection process can cause morphological alterations whether the immersion period was exceeded. Also, these solutions can influence on the obturation sealing.
\end{abstract}

\section{KeYWORDS}

Peracetic acid; Chlorhexidine; Gutta-percha; Sodium hypochlorite; Tooth leakage.

\section{Resumo}

Objetivo: Essa pesquisa avaliou as alterações morfológicas, em microscopia eletrônica de varredura (MEV), que ocorrem na superfície dos cones de guta-percha em períodos excedidos aos preconizados. Material e método: Clorexidina 2\% (CLX), hipoclorito de sódio 2,5\% (NaOCL), ácido peracético 2\% (AP) e solução de ácido peracético $0,25 \%$ (SAP) foram as soluções utilizadas nos períodos de $1 \mathrm{~min}, 30 \mathrm{~min}, 6 \mathrm{~h}$ e $12 \mathrm{~h}$. Os grupos foram divididos de acordo com a solução e período de desinfecção $(n=12)$. Resultados: Os resultados indicaram que houve diferença estatística significante entre as soluções e períodos testados. Em $1 \mathrm{~min}$, todas as soluções não diferiram do controle. Após $30 \mathrm{~min}$, a SAP alterou significativamente a morfologia dos cones. $\mathrm{O}$ teste de espectrometria de energia dispersiva (EDS) indicou que todas as substâncias e períodos alteram a composição química dos cones de guta-percha. A relação da desinfecção na microinfiltração da obturação também foi avaliada nos grupos que sofreram desinfecção por $12 \mathrm{~h}$. O grupo da SAP apresentou diferença estatística significante em relação ao controle, pois $100 \%$ das suas raízes apresentaram infiltração. Os demais grupos da CLX, NaOCL e AP, embora sem diferença estatística significante, tiveram respectivamente 9,8 e 8 do total de 12 das suas raízes com infiltração. Conclusão: Conclui-se que o processo de desinfecção pode causar alterações morfológicas se o período de imersão for excedido e que, além de alterarem a composição química dos cones de guta-percha, estas soluções podem influenciar no selamento da obturação.

\section{Palavras-chave}

Ácido peracético; Clorexidina; Guta-percha; Hipoclorito de sódio; Infiltração dentária. 


\section{INTRODUCTION}

One of the goals of the endodontic obturation is to fill the root canals with materials, hermetically sealing the root canals system [1]. Currently, the materials meeting the requirement for a satisfactory obturation of root canals are the endodontic cements and guttapercha points.

Gutta-percha shows favorable properties because of its easy handling; low cost; good biocompatibility, radiopacity and plasticity; reasonable dimensional stability; with easy removal in the presence of organic solvents; not causing the staining of the tooth structure, and being insoluble to the organic fluids [2].

Although gutta-percha points are produced under aseptic conditions and show great antimicrobial potential because of zinc oxide incorporation [35], some studies identified commercially available gutta-percha points contaminated either by the manufacturing process or by warehousing and storage [5-7]. Also, they may be contaminated by either aerosols or handling during its use because there are several points in a same box. Therefore, even if the package is sealed, the points are not suitable for immediate use, and should undergo a chemical disinfection process because gutta-percha is a thermolabile material and it cannot be sterilized through heat [7-12].

Several solutions can be used for the disinfection of gutta-percha points prior to root canal system obturation, among them, sodium hypochlorite, chlorhexidine, iodinated alcohol and peracetic acid $[7,13]$. However, morphological alterations may be observed on gutta-percha points when these are kept immersed into these solutions for longer periods [1315]. These alterations on gutta-percha points after disinfection may compromise the standardization of the points, making difficult their adaptation to root canal walls $[13,14,16-19]$.

Based on this aforementioned information, this study employed $2.5 \%$ sodium hypochlorite, $2 \%$ chlorhexidine, in situ $2 \%$ peracetic acid, and a solution containing $0.25 \%$ peracetic acid as disinfecting agents of gutta-percha points, aiming to evaluate: (1) the effect that these disinfecting solutions may provoke on the surface of gutta-percha points, after exposure to periods longer than $1 \mathrm{~min}$, (2) which alterations occur in their chemical composition after disinfection and (3) the influence of the morphological alterations of the gutta-percha points on the sealing of the obturation through leakage assessment.

\section{Material And Method}

This research was submitted and approved by the Ethical Committee in Research on Human Beings of the School of Dentistry of São José dos Campos, under protocol n. 018/2010-PH/CEP.

\section{Morphological analysis in SEM}

Two hundred and four size 30 taper 04 guttapercha points (Dentsply/Maillefer, Petrópolis, RJ, Brazil), were divided into 17 groups $(n=12)$. Group G0 comprised the negative control, where the points were used without any disinfection treatment. Groups G1, G2, G3 and G4 were the positive controls, where the disinfection period was of $1 \mathrm{~min}$. Groups from G5 to G16 the points were divided according to the disinfecting solution and periods employed (Table 1).

The following disinfecting solutions were used: $2 \%$ chlorhexidine solution (CLX) (manipulated in Manipulation Pharmacy - Naturaville, Barueri, SP, Brazil); in situ 2\% peracetic acid (PA) (Sekusept Aktiv ${ }^{\circledR}$, Henkel-Ecolab, Germany); $0.25 \%$ peracetic acid solution with hydrogen peroxide and stabilizer vehicle (PAS) (Proxitane Alfa $\AA$, Semmper Representações, São Paulo, SP, Brazil); $2.5 \%$ sodium hypochlorite (NaOCL) (Terapêutica Farmácia de Manipulação, São José dos Campos, SP, Brazil).

The disinfection periods were the same for all solutions: $1 \mathrm{~min}, 30 \mathrm{~min}, 6 \mathrm{~h}$ and $12 \mathrm{~h}$.

\section{TABLE 1 - GROUP DIVISION}

\begin{tabular}{c|c|c|}
\hline Groups & Solution & $\begin{array}{c}\text { Disinfection } \\
\text { Period }\end{array}$ \\
\hline$G 0(n=12)$ & Without disinfection & \\
\hline$G 1(n=12)$ & $2 \%$ chlorhexidine & $1 \mathrm{~min}$ \\
\hline$G 2(n=12)$ & $2 \%$ peracetic acid & $1 \mathrm{~min}$ \\
\hline$G 3(n=12)$ & $0.25 \%$ peracetic acid solution & $1 \mathrm{~min}$ \\
\hline$G 4(n=12)$ & $2.5 \%$ sodium hypochlorite & $1 \mathrm{~min}$ \\
\hline$G 5(n=12)$ & $2 \%$ chlorhexidine & $30 \mathrm{~min}$ \\
\hline$G 6(n=12)$ & $2 \%$ chlorhexidine & $6 \mathrm{~h}$ \\
\hline$G 7(n=12)$ & $2 \%$ chlorhexidine & $12 \mathrm{~h}$ \\
\hline$G 8(n=12)$ & $2 \%$ peracetic acid & $30 \mathrm{~min}$ \\
\hline$G 9(n=12)$ & $2 \%$ peracetic acid & $6 \mathrm{~h}$ \\
\hline$G 10(n=12)$ & $2 \%$ peracetic acid & $12 \mathrm{~h}$ \\
\hline$G 11(n=12)$ & $0.25 \%$ peracetic acid solution & $30 \mathrm{~min}$ \\
\hline$G 12(n=12)$ & $0.25 \%$ peracetic acid solution & $6 \mathrm{~h}$ \\
\hline$G 13(n=12)$ & $0.25 \%$ peracetic acid solution & $12 \mathrm{~h}$ \\
\hline$G 14(n=12)$ & $2.5 \%$ sodium hypochlorite & $30 \mathrm{~min}$ \\
\hline$G 15(n=12)$ & $2.5 \%$ sodium hypochlorite & $6 \mathrm{~h}$ \\
\hline$G 16(n=12)$ & $2.5 \%$ sodium hypochlorite & $12 \mathrm{~h}$ \\
\hline
\end{tabular}


The tips of the gutta-percha points undergone disinfection were sectioned at $4 \mathrm{~mm}$ short of the apex, comprising the thinnest extremity of the root, to be submitted to the superficial morphological analysis on Scanning Electronic Microscopy (SEM) (Scanning microscope - JSM - 840 ${ }^{\mathrm{a}}$ Jeol, Tokyo, Japan), at x500 magnification.

The images obtained were analyzed visually by a single calibrated examiner. The alterations on the surface of the points were ordered to define the alteration pattern through scores, where 0 (zero) corresponded to the natural roughness of the guttapercha points because of manufacturing process, while 1,2 and 3 respectively corresponded to little, very and completely altered.

\section{Chemical analysis in EDS}

At this stage, the chemical analysis of the guttapercha points of groups G0, G3, G7, G10, G13 and G16 through EDS ( Energy Dispersive Spectrometry), conducted at the National Institute for Space Research (INPE -, São José dos Campos - SP, Brazil). These groups were selected because they exhibited the greatest morphological alterations. Thus, the other groups would probably exhibit intermediary data. The EDS assessments quantified the following chemical elements: C (carbon), O (oxygen), $\mathrm{Al}$ (aluminum), $\mathrm{S}$ (sulfur), P ( phosphorus), Zn (zinc), Ba ( barium), Si (silicon), $\mathrm{Na}$ (sodium) and $\mathrm{Cl}$ ( chlorine).

\section{Leakage analysis}

The same groups of the last stage were analyzed at this phase. For SEM analysis, gutta-percha points were metalized with thin gold layer, making impossible their posterior use. Then, new points undergone the same disinfection process of the last stage and the obturation was performed in single-rooted teeth after biomechanical preparation together with $\mathrm{AH}$ Plus endodontic sealer.

Tooth crowns were removed to standardize the roots at $14 \mathrm{~mm}$. Apical stop was determined at $1 \mathrm{~mm}$ short of the apex with the aid of a size 30 Kerr file through progressive enlargement technique up to size 45 Kerr file. At every instrument change, irrigation was performed with $5 \mathrm{ml}$ of $1 \%$ sodium hypochlorite $(\mathrm{NaOCl})$. At the ending of the instrumentation, the canals were filled with EDTA solution for $3 \mathrm{~min}$ to remove the smear layer, followed by a new irrigation with $5 \mathrm{ml}$ of $1 \% \mathrm{NaOCl}$ to remove EDTA and final irrigation with $10 \mathrm{ml}$ of saline solution.
After the biomechanical preparation, a size 30 taper 04 main gutta-percha point (Dentsply/Maillefer, Petrópolis, RJ, Brazil) was selected and locked at 1 $\mathrm{mm}$ short of the apical foramen. The auxiliary points were also immersed into the disinfecting solutions for periods similar to those of the main points, according to their group. Next, the roots were filled with AH Plus sealer (Dentsply/Maillefer, Petrópolis, RJ, Brazil) through single cone and passive lateral condensation techniques.

After obturation, the roots were externally waterproofed (except from $2 \mathrm{~mm}$ short of the apex) by using two layers of red nail polish and one layer of sticky wax. After that, the roots were immersed into Indian ink to perform the microleakage test. Following, the roots were diaphanized through 5\% hydrochloric acid, increasing alcohol solutions and clarification with methyl salicylate. The roots were photographed in stereomicroscope coupled to a digital camera and the measurements of apical microleakage executed through Adobe Illustrator CS4 software (Adobe Corporation), which allowed to obtain the measurements in millimeters, according to a line manually traced on the image formed by the ink from the root apex towards the most coronal part of the Indian ink leakage.

\section{Results}

Superficial morphological alterations on guttapercha points

The superficial morphological alterations were assessed according to the following scores: 0 surface with standard alteration; 1 - surface with little alterations; 2 - surface with many alterations and 3 surface completely deformed. Only PAS exhibited the greatest scores. At all periods, $\mathrm{NaOCl}, \mathrm{PA}$ and CLX solutions presented scores between 0 and 1 (Figure 1).

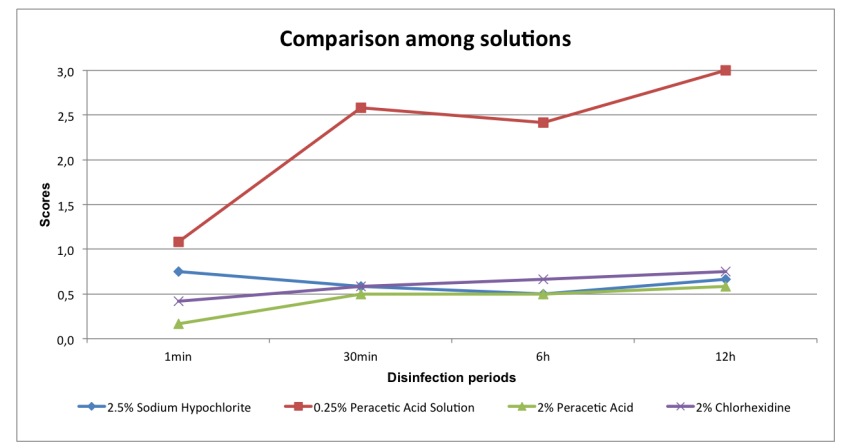

Figure 1 - Comparison among the solutions according to the disinfection time. 


\section{Statistical analysis of the groups}

All tests were executed through statistix 8.0 software. When Kruskal-Wallis test was applied, there were statistical significant differences among all groups tested $(\mathrm{p}=0.00001<0.05)$. Thus, Dunn test $(5 \%)$ was applied and homogenous groups were obtained (Table 2). The critical value of comparison was 85.853 .

\section{TABLE 2 - Homogenous gROUPS}

\begin{tabular}{|c|c|c|c|}
\hline Groups & Period & Median & $\begin{array}{l}\text { Homogenous } \\
\text { groups }\end{array}$ \\
\hline $\begin{array}{l}0.25 \% \text { peracetic acid } \\
\text { solution }(\mathrm{G} 13)\end{array}$ & $12 \mathrm{~h}$ & 191.00 & A \\
\hline $\begin{array}{l}0.25 \% \text { peracetic acid } \\
\text { solution }(\mathrm{G} 11)\end{array}$ & $30 \mathrm{~min}$ & 180.83 & $A B$ \\
\hline $\begin{array}{l}0.25 \% \text { peracetic acid } \\
\text { solution }(\mathrm{G} 12)\end{array}$ & $6 \mathrm{~h}$ & 175.29 & $A B C$ \\
\hline $\begin{array}{l}0.25 \% \text { peracetic acid } \\
\text { solution }(\mathrm{G} 3)\end{array}$ & $1 \mathrm{~min}$ & 108.67 & $A B C D$ \\
\hline $2 \%$ chlorhexidine (G7) & $12 \mathrm{~h}$ & 103.63 & $\mathrm{BCD}$ \\
\hline $\begin{array}{l}2.5 \% \text { sodium hypochlorite } \\
\text { (G4) }\end{array}$ & $1 \mathrm{~min}$ & 100.67 & BCD \\
\hline $\begin{array}{l}2.5 \% \text { sodium hypochlorite } \\
\text { (G16) }\end{array}$ & $12 \mathrm{~h}$ & 96.66 & $B C D$ \\
\hline $2 \%$ chlorhexidine (G6) & $6 \mathrm{~h}$ & 96.66 & $\mathrm{BCD}$ \\
\hline $2 \%$ peracetic acid $(\mathrm{G} 10)$ & $12 \mathrm{~h}$ & 89.70 & CD \\
\hline $\begin{array}{l}2.5 \% \text { sodium hypochlorite } \\
\text { (G14) }\end{array}$ & $30 \mathrm{~min}$ & 89.70 & $C D$ \\
\hline $2 \%$ chlorhexidine (G5) & $30 \mathrm{~min}$ & 89.70 & $C D$ \\
\hline $\begin{array}{l}2.5 \% \text { sodium hypochlorite } \\
\text { (G15) }\end{array}$ & $6 \mathrm{~h}$ & 82.75 & $\mathrm{D}$ \\
\hline $2 \%$ peracetic acid (G8) & $30 \mathrm{~min}$ & 82.75 & $\mathrm{D}$ \\
\hline $2 \%$ peracetic acid (G9) & $6 \mathrm{~h}$ & 82.75 & $\mathrm{D}$ \\
\hline $2 \%$ chlorhexidine (G1) & $1 \mathrm{~min}$ & 75.79 & $\mathrm{D}$ \\
\hline $2 \%$ peracetic acid (G2) & $1 \mathrm{~min}$ & 54.91 & $\mathrm{D}$ \\
\hline Without disinfection (G0) & ------ & 41.00 & D \\
\hline
\end{tabular}

\section{Comparison of the chemical analysis among G0, G3, G7, G10, G13 and G16}

Zinc and Oxygen, respectively, were the elements at higher percentage found in groups G0, G10 and G16. On the other hand, in groups G7 and G13, Oxygen was predominantly present in the guttapercha points, followed by Zinc. In G3 there was a chemical decharacterization of the gutta-percha pointe with predominance of oxygen, sulfur, and barium at decreasing order of concentration. There was a great variety at the concentrations of the chemical elements, regardless of the solution and time period employed (Figure 2).

\section{Analysis of the marginal sealing of the canals filled with $\mathrm{AH}$ Plus through leakage and diaphanization process of the roots}

There were statistically significant differences among groups because $\mathrm{p}<0.05(\mathrm{p}=0.0014)$. According to Dunn test at 5\%, the groups G3, G7 and G16 did not differ from groups G0, G10 and G13. Groups G0 and G10 (roots filled with points disinfected for $12 \mathrm{~h}$ with $2 \%$ peracetic acid) exhibited statistically significant difference in relation to G13 $(0.25 \%$ peracetic acid solution for $12 \mathrm{~h}$ ). The descriptive statistics of the leakage values and the division of the homogenous groups are seen in Tables 3 and 4.

Table 3 - Descriptive statistics of the MICROLEAKAGE VALUES (MM) IN THE GROUPS EVALUATED

\begin{tabular}{c|c|c|c|c|c|c|c|c|c}
\hline Groups & N & Mean & SD & C.V.(\%) & Min & Q1 & Median & Q3 & Max \\
& & & & & & & & & \\
\hline G0 & 12 & 2.30 & 6.24 & 271.78 & 0.00 & 0.00 & 0.00 & 0.00 & 21.27 \\
\hline G3 & 12 & 1.90 & 3.83 & 201.93 & 0.00 & 0.00 & 0.00 & 3.32 & 13.07 \\
\hline G7 & 12 & 7.03 & 7.31 & 103.97 & 0.00 & 0.87 & 4.50 & 9.67 & 21.55 \\
\hline G10 & 12 & 7.80 & 7.93 & 101.60 & 0.00 & 0.00 & 6.76 & 15.36 & 20.85 \\
\hline G13 & 12 & 13.36 & 9.07 & 67.91 & 0.84 & 4.44 & 15.90 & 20.33 & 28.41 \\
\hline G16 & 12 & 13.29 & 18.02 & 135.67 & 0.00 & 0.00 & 3.38 & 30.72 & 53.02 \\
\hline
\end{tabular}

G0- without disinfection; G3- $0.25 \%$ peracetic acid solutions, $1 \mathrm{~min} ; \mathrm{G} 7-2 \%$ chlorhexidine, $12 \mathrm{~h}$; G10- $2 \%$ peracetic acid, 12 h; G13- 0.25\% peracetic acid solution, 12 h; G16- 2.5\% sodium hypochlorite, $12 \mathrm{~h}$.

TABLe 4 - Homogenous groups of leakage INFILTRATION.

\begin{tabular}{c|c}
\hline Group & Homogenous Groups \\
\hline G0 & B \\
\hline G3 & AB \\
\hline G7 & AB \\
\hline G10 & B \\
\hline G13 & A \\
\hline G16 & AB \\
\hline
\end{tabular}

G0- without disinfection; G3- $0.25 \%$ peracetic acid solutions, $1 \mathrm{~min}$; G7- 2\% chlorhexidine, 12 h; G10- 2\% peracetic acid, 12 h; G13- $0.25 \%$ peracetic acid solution, 12 h; G16- $2.5 \%$ sodium hypochlorite, $12 \mathrm{~h}$. 
According to Figure 3, all groups had at least two roots with ink leakage. The group exhibiting the least leakage was G0; followed by the groups G3, G10, G16 and G7. On the other hand, G13 showed leakage in all the roots filled with gutta-percha points submitted to disinfection with $0.25 \%$ peracetic acid solution for $12 \mathrm{~h}$, but without statistically significant differences among groups G7, G10 and G16 (respectively filled with gutta-percha points disinfected for $12 \mathrm{~h}$ with $2 \%$ chlorhexidine, $2 \%$ peracetic acid and $2.5 \%$ sodium hypochlorite); however there were statistically significant differences in relation to control group.

SEM images also identified microporosities at x200 magnification (Figure 4 A). On the surface of the points submitted $2.5 \% \mathrm{NaOCl}$, chloride crystals were observed. On the other hand, on the points disinfected with $0.25 \%$ peracetic solution, apparently there was the lysis of the chemical components (Figure 4 B).

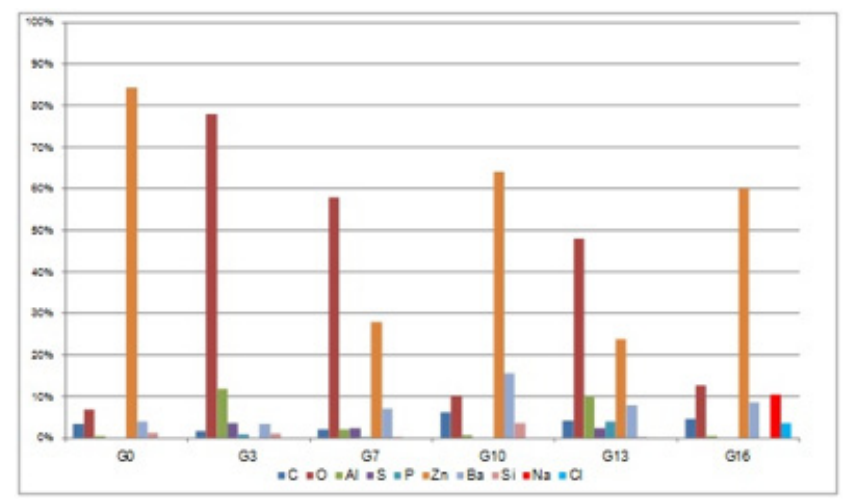

Figure 2 - Comparative graph of the percentages of the chemical elements of groups GO, G3, G7, G10, G13 and G16.

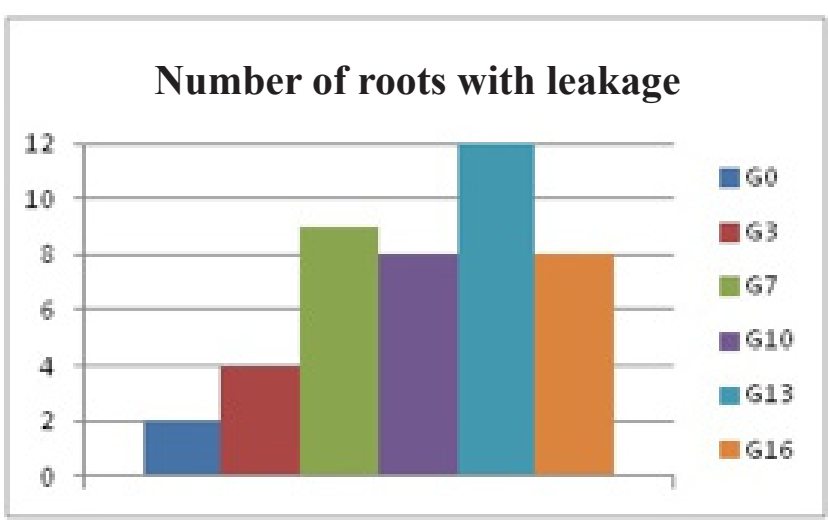

Figure 3 - Graph of the number of roots showing microleakage per group.
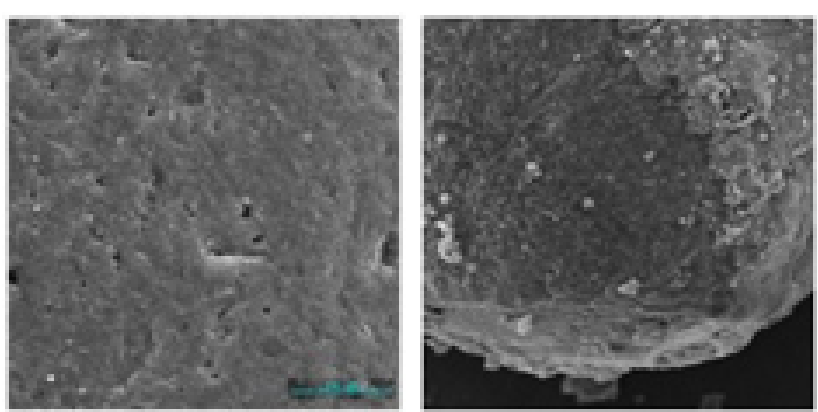

Figure 4 - A) Gutta-percha point at x2000 magnification in SEM evidencing microporosities; B) Image of a guttapercha point evidencing the lysis of components.

\section{Discussion}

This present study evaluated the morphological and chemical alterations because of the disinfection with sodium hypochlorite, chlorhexidine and peracetic acid solutions at different time periods as well as the influence of these alterations on the sealing of the obturation of the root canal system. The results of this present study showed that the surface of the points, when analyzed through SEM, did not undergo severe morphological alterations at x500 magnification for sodium hypochlorite, peracetic acid and chlorhexidine at different time periods. Notwithstanding, the guttapercha points submitted to disinfection with peracetic acid exhibited severe morphological alterations on their surface, which were increased as the immersion time went by.

These results are in agreement with those of a study conducted by Lopes et al. [20] who evaluated through SEM the surface of gutta-percha points after disinfection for 30 min with $2 \%$ chlorhexidine and 5\% sodium hypochlorite, concluding that the surface of gutta-percha points did not undergo severe alterations when analyzed at $\mathrm{x} 150$ to $\mathrm{x} 300$ magnification; however, at $\mathrm{x} 3000$ magnification, microporosities were present. Although this was not the aim of the study, at x2000 magnification, microporosities were also observed on gutta-percha points. One of the suggestive reasons for these alterations is the oxidative power of these solutions by breaking the polymer chains causing structural deformities on a range of materials [21-23].

According to this present study, EDS test exhibited quantitative changes in the chemical elements of the points, when compared with the points without disinfection of the control group. EDS revealed that the disinfection with $2.5 \%$ sodium hypochlorite the oxygen amount increases in approximately 50\%, 
proving the great oxidative potential of the solution [23]. In addition to this element, chloride and sodium, which had not been detected in the control group, was detected at all periods, justifying the presence and permanence of chloride crystals [18].

Short et al. [18] and Moller and Orstavik [24], in EDS analysis, found that the chemical elements most present in gutta-percha points are zinc and barium; unlikely to this present study where zinc $(84,39 \%)$ and oxygen $(6,73 \%)$ appeared at higher amounts. Barium is present at a concentration of $3.86 \%$ and probably is included to provide radiopacity to gutta-percha points [24]. If the gutta-percha points are composed at their greatest part of zinc oxide (59\% to $79 \%$ ), gutta-percha $(19 \%$ to $22 \%)$ and, at their smallest part of heavy metal salts $(1 \%$ to $17 \%)$ and wax or resin $(1 \%$ to $4 \%)$ [25], it is acceptable that zinc and oxygen is really at higher concentrations.

Peracetic acid is a powerful biocide agent and requires only one min for promoting the disinfection of gutta-percha points [26]. The main advantages of this chemical agent are the fact of remaining active in the presence of organic matter and exhibiting acetic acid and oxygen as decomposition products [27]. The results obtained in EDS test, where the points underwent little oxygen $(\mathrm{O})$ increase, can be justified by the releasing of oxygen to the environment and without penetrating into the gutta-percha points. SEM images proved such fact.

On the other hand, gutta-percha points undergone disinfection with $0.25 \%$ peracetic acid solution and hydrogen peroxide had their surface altered from $1 \mathrm{~min}$ and this was proportional to the immersion period. There was a great quantitative variation of the chemical elements. The formulation of the peracetic acid solution shows high bactericidal potential because both chemical agents have such property $[26,28]$.

EDS analyses revealed that at the first min of disinfection with peracetic acid solution, oxygen was the chemical element most found in the gutta-percha points $(77.94 \%)$, and it had its amount expressively increased when compared with control group $(6.73 \%)$. On the other hand Zinc (Zn) was completely eliminated after one min. With the increasing of the immersion time to $12 \mathrm{~h}, \mathrm{O}$ was the predominant element; however, at smaller amount (47.99\%); Zn increased to $23.68 \%$ in the composition of guttapercha points. The other chemical elements also had their amounts altered, by mixing the organic and inorganic portions of gutta-percha points.

According to Budavari [23], the free oxygen acts on gutta-percha which becomes frangible. Although peracetic acid is at smaller concentration $(0.25 \%)$ in this solution, there was the presence of the oxygen released not only because of the decomposition of the peracetic acid, but also because of the action of the hydrogen peroxide. Such data demonstrated the powerful degenerative action of this solution and the lysis of the components of the gutta-percha points, initially on the superficial layer and posteriorly reaching the deepest layers.

Himel et al. [25] recommended the washing with alcohol of the points after the disinfection and prior to the obturation to remove the crystals formed from sodium hypochlorite. Some researches proved the presence of solid particles on the surface of guttapercha points undergoing disinfection with sodium hypochlorite and also affirmed that such crystals on the surface of gutta-percha points may hinder the obturation sealing $[13,18,20]$.

The diaphanization was the method of choice to analyze the apical sealing through Indian ink leakage because it is a simple and low cost technique enabling the tridimensional visualization of the roots [29]. It was possible to evaluate that even with the presence of endodontic cement, there were differences in the leakage of the obturation between control and G13 groups $(0.25 \%$ peracetic acid solution), the group most damaged. A study conducted by Prado et al. [30], concluded that gutta-percha points immersed in sodium hypochlorite and chlorhexidine for $1 \mathrm{~min}$, increased the free energy surface of the gutta-percha point, promoting a high interaction between it and the endodontic cement. Therefore, these authors suggested that the disinfecting solutions lead to an increase in the surface wettability of the guttapercha thus interfering positively with the adhesion mechanism. Also, they affirmed that this alteration may occur because of the chemical modification on the surface of these materials provoked by the action of the disinfecting solutions.

However, although the morphological alterations are not generally the main causes of a poor obturation, the obturation with a gutta-percha point maladapted to the apical stop in addition to morphological alteration on its surface may facilitate apical microleakage because of lack of sealing of root canal, therefore, jeopardizing the obturation. Thus, it can be concluded that at periods longer than $1 \mathrm{~min}$, the disinfecting solutions influence on apical sealing failure because they promote irreversible alterations on gutta-percha points, and therefore, the disinfection period should not be extended beyond the minimum necessary. 


\section{Conclusions}

Based on the results of this study, it can be concluded that:

1. The disinfecting solutions cause superficial morphological alterations on the gutta-percha points because of their oxidative power; also, these alterations were proportional to the period for which the points were immersed into the solutions;
2. The points underwent a chemical decharacterization, with predominance of oxygen after the disinfection and time periods tested;

3. The disinfection of the gutta-percha points should be performed for the shortest period recommended so that the morphological alterations are minimum, once very altered gutta-percha points would influence on the apical sealing and increase microleakage.

\section{RefERENCES}

1. Siqueira JF Jr, Rôças IN, Valois CR. Apical sealing ability of five endodontics sealers. Aust Endod J 2001; 27:33-35.

2. Leonardo MRL. Endodontia: conceitos biológicos e recursos tecnológicos. São Paulo: Artes Médicas; 2009

3. Moorer WR, Genet JM. Evidence for antibacterial activity of endodontic gutta-percha cones. Oral Surg Oral Med Oral Pathol. 1982;53(5):503-7

4. Santos RB, Poisl MIP, Mattielo VS. Esterilidade dos cones de guta-percha, mito ou realidade? / Sterelity of guta-percha points, myth or reality? Rev Bras Odontol. 1999;56(5):2013.

5. Fagundes FS, Leonardi DP, Haragushiku GA, Baratto Filho F, Tomazinho LF, Tomazinho PH. Rev. Sul-Bras Odontol. 2005; 2(2):7-11.

6. Namazikhah MS, Sullivan DM, Trnavsky GL. Gutta-percha: a look at the need for sterilization. J Calif Dent Assoc. 2000;28:427-32.

7. Gomes BPFA, Vianna ME, Matsumoto CU, Rossi VPS, Zaia AA, FerrazCCR, Souza-Filho FJ. Disinfection of gutta-percha cones with chlorhexidine and sodium hypochlorite. Oral Surg Oral Med Oral PatholOral Radiol Endod. 2005;100(4):512-7.

8. Gomes BPFA, Ferraz CCR, Carvalho KC, Teixeira FB, Zaia AA, Souza-Filho FJ. Descontaminação química de cones de guta-percha por diferentes concentrações de NaOCl. Rev Assoc Paul Cir Dent. 2001;55(1):27-31

9. Souza RE, de Souza EA, Sousa Neto MD, Pietro RC. In vitro evaluation of different chemical agents for the decontamination of gutta-percha cones. Pesqui Odontol Bras. 2003;17(1):75-7.

10. Ozalp N, Okte Z, Ozcelik B. The rapid sterilization of guttapercha cones with sodium hypochlorite and glutaraldehyde. J Endod. 2006;32(12):1202-4.

11. Silva CHFP, Siqueira Jr JFC, Cerqueira MDO, Guimarães MA, Lopes HP. Uso de água sanitária na esterilizaçäo rápida de cones de gutta-percha/Rapid sterilization of sanitary water. JBC 2000;4(23):77-9.

12. Bortoloni MCT. Descontaminação de Guta-percha. Rev Uningá.2007;11(1)11-22.

13. Pang NS, Jung Y, Bae K, Baek S, Lee W, Kum K. Effects of short-term chemical disinfection of gutta-percha cones: Identification of affected microbes and alterations in surface texture and physical properties. J Endod. 2007;33(5):594-8.

14. Valois CRA, Silva LP, Azevedo RB. Structural effects of sodium hypochlorite solutions on gutta-percha cones: atomic force microscopy study. J Endod. 2005;31(10):749-51.
15. Brito SMSM. Análise morfológica da superfície dos cones de guta-percha submetidos à desinfecção com hipoclorito de sódio a $1 \%$ e a $2 \%$ e sua influência no selamento marginal da obturação [tese]. São José dos Campos: Faculdade de Odontologia de São José dos Campos, UNESP - Univ Estadual Paulista; 2007.

16. Goldberg F, Gurfinkel J, Spielberg C. Microscopic study of standardized gutta-percha points. Oral Surg Oral Med Oral Pathol. 1979;47(3):275-6.

17. Goldberg F, Massone EJ, Pruskin E, Zmener O. SEM study of surface architecture of gutta-percha cones. Endod Dent Traumatol. 1991;7:15-8.

18. Short RD, Dorn SO, Kuttler S. The crystallization of sodium hypochlorite on gutta-percha cones after the rapid-sterilization technique: an SEM study. J Endod. 2003;29(10):670-3.

19. Valois CRA, Silva LP, Azevedo RB, Costa Jr ED. Atomic force microscopy study of gutta-percha cone topography. Surg Oral Med Oral Pathol Oral Radiol Endod. 2004;98(2):250-5.

20. Lopes HP, Elias CN, Estrela C. Analyses of the gutta-percha cones after the chemical sterilization. Braz Endod J. 1997;2(1):35-6.

21. Berutti E, AngeliniE, Rigolone M, Migliaretti G, Pasqualini D. Influence of sodium hypochlorite on fracture properties and corrosion of protaper rotary instruments. Int Endod J 2006;39:693-699.

22. Yamauti M, Hashimoto M, Sano H, Ohno H, Carvalho RM, Kaga M, Tagami J, Ogguchi H, Kubota M. Degradation of resin-dentin bonds using $\mathrm{NaOCl}$ storage. Dent Mater 2003;19:399-405.

23. Budavari S. The Merck index: an encyclopedia of chemicals, drugs, and biologicals. Whitehouse Station: Merck; 1996.

24. Moller B, Orstavik D. Chemical and energy-dispersive X-ray analyses of gutta-percha points. J Endod. 1984;10(9):413-6.

25. Himel VT, Mc Spadden JT, Goodis HE. Instrumentos, materiais e aparelhos. Em:Cohen S, Hargreaves KM, editores. Caminhos da Polpa. Rio de Janeiro: Elsevier; 2007.

26. Salvia ACRD, Teodoro GR, Koga-Ito CY, Oliveira SHG. Effectiveness of $2 \%$ peracetic acid for the disinfection of guttapercha cones. Bras Oral Res. 2011;25(1):23-7

27. Silva FCP, Pradella TC, Navas EAFA, Claro PARA, KogaIto CY, Jorge AOC. Influência de agentes desinfetantes sobre a aderência de Staphylococcus aureus em aço inoxidável. Ciênc. Odontol. Bras.2008;11(3):60-5.

28. Linke HAB, Chohayeb AA. Effective surface sterilization of gutta-percha points. Oral Surg Oral Med Oral Pathol. 1983;55(1):73-7.

29. Libera LD, Arruda MP, Barato Filho F, Cavali AEC, Souza- 
Neto MD,Ferraz JAB. Estudo in vitro da infiltração marginal apical de canais obturados pela técnica termomecânica híbrida com e sem a remoção do smear layer. Rev ABO Nac. 2005;13(3):184-7.

30. Prado M, Assis DF, Gomes BPFA, Simão RA. Effect of disinfectant solutions on the surface free energy and wettability of filling material. Int Endod J 2011;37(7):980-2.
Received: 2012 Sept. 24

Accepted: 2012 Nov. 26

Corresponding author:

Simone Helena Gonçalves de Oliveira Endereço: Eng Francisco José Longo, nº 777 - Jardim São Dimas

São José dos Campos - SP,12245-000. Email: odontologia.integrada@uol.com.br 